\section{Cureus}

Received 05/03/2014

Review began 05/04/2014

Review ended 05/12/2014

Published 05/13/2014

\section{(C) Copyright 2014}

Mortazavi et al. This is an open access article distributed under the terms of the Creative Commons Attribution License CC-BY 3.0., which permits unrestricted use, distribution, and reproduction in any medium, provided the original author and source are credited.

\title{
Multiple Aneurysms on Inter-PICA Communicating Collaterals: Case Report on a Rare Entity
}

\author{
Martin M. Mortazavi ${ }^{1}$, Jason M. Frerich ${ }^{2}$, Laligam N. Sekhar ${ }^{3}$ \\ 1. California Institute of Neuroscience, Los Robles Hospital and Medical Center 2. Department of \\ Neurological Surgery, Emory University School of Medicine 3. Department of Neurosurgery, University of \\ Washington School of Medicine, Seattle, WA
}

$\square$ Corresponding author: Jason M. Frerich, jmfrerich@gmail.com

Disclosures can be found in Additional Information at the end of the article

\section{Abstract}

Aneurysms arising from the posterior inferior cerebellar artery (PICA) to PICA communicating collaterals are very rare. Only five cases have so far been described in the literature. Here, we report the first case with multiple aneurysms occurring on separate inter-PICA communicating collateral arteries, where one of the PICA's was occluded proximally and reconstituted distally through the inter-PICA collateral arteries, in a patient presenting with subarachnoid hemorrhage. After standard management, the ruptured aneurysm was resected, and the other unruptured aneurysm was clipped. Side-to-side PICA-to-PICA anastomosis distal to the communicating collaterals was performed in order to maintain collateral circulation to the brainstem. Clinicians should be aware of the possibility of these rare aneurysms, and should consider in situ bypass in the management of PICA aneurysms where the aneurysm is proximal to the telovelotonsillary segment of PICA.

Categories: Neurosurgery

Keywords: aneurysm, posterior inferior cerebellar artery, subarachnoid hemorrhage, arterial anastomosis

\section{Introduction}

The posterior inferior cerebellar artery (PICA) is a tortuous artery with extensive anatomical variation [1-2]. PICA aneurysms are rare, representing $0.49-3 \%$ of all intracranial aneurysms [34]. The majority of PICA aneurysms develop at the anterior medullary segment at the junction of the PICA and the vertebral artery (VA) [3, 5]. Zero point nine to $5.2 \%$ of all PICA aneurysms arise distal to the anterior medullary segment [4-6]. Most of the aneurysms develop proximal to the telovelotonsillary segment [3, 5]. Aneurysms arising from small perforating arteries of PICA are exceptionally rare, with only eight cases described in the literature [4, 7-18]. PICA-to-PICA "communicating collateral" aneurysms are even rarer, with only five cases reported [4, 7-10].

Here, we report a case of a ruptured aneurysm arising from an inter-PICA communicating collateral artery at the telovelomedullary segment, along with a similar but smaller unruptured aneurysm from an adjacent inter-PICA communicating collateral. This case is unique in several respects. To the authors' knowledge, it is the only case reported with one aneurysm on each of multiple inter-PICA communicating collaterals. Furthermore, it is also the only reported case were side-to-side PICA-to-PICA bypass was performed beyond the communicating collaterals in an attempt to increase the circulation on the side of the proximally occluded PICA. 


\section{Cureus}

\section{Case Presentation}

History and Physical Examination

A 76-year-old right-handed Caucasian female with history of hypertension presented with acute onset of severe headache. She was intubated at the local emergency room and was transferred to our facility for further management. Initial CT head demonstrated significant subarachnoid hemorrhage with a bleeding pattern typical of lower posterior circulation hemorrhage (Figures 1A, 1B).
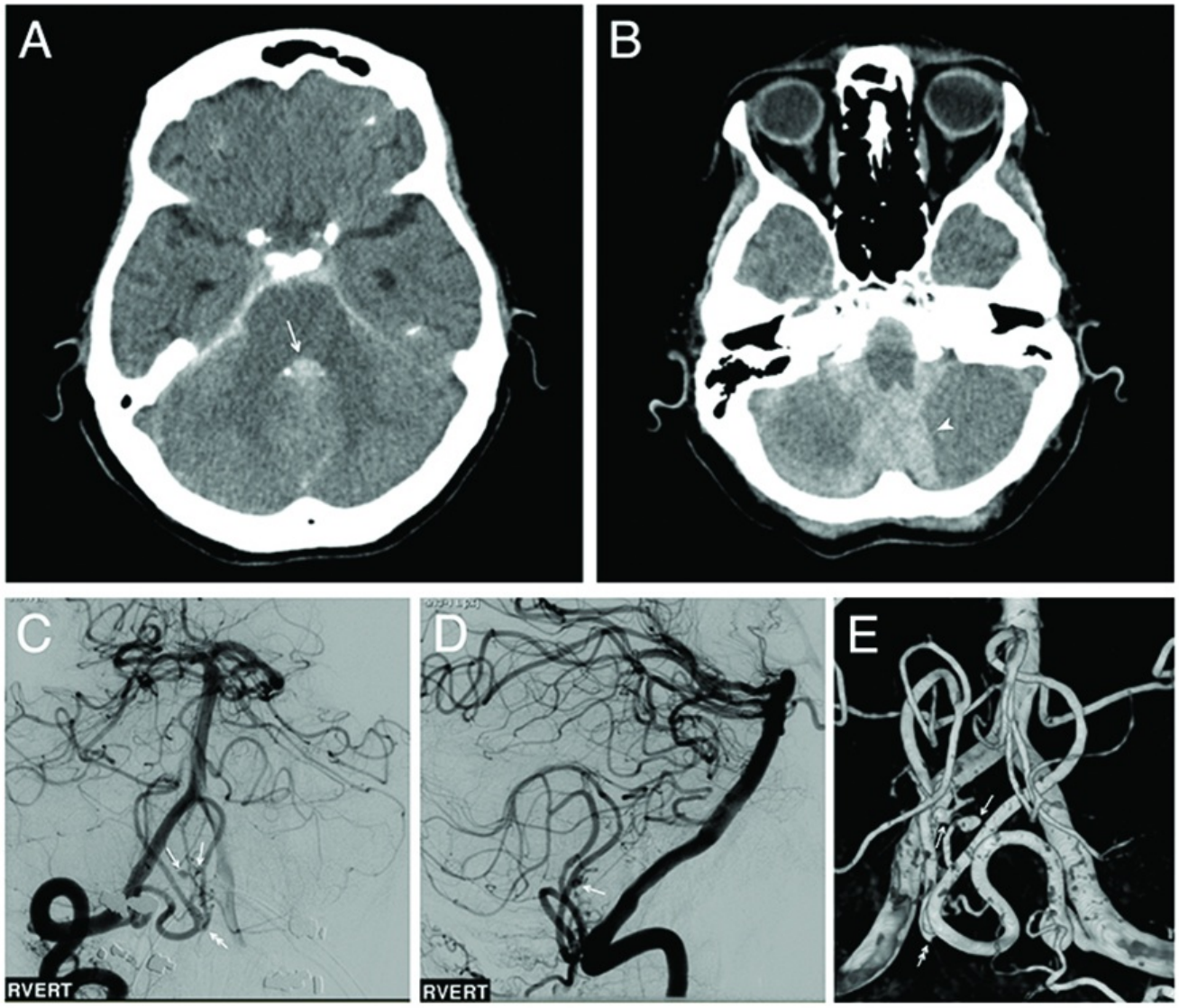

\section{FIGURE 1: Preoperative computed tomography (CT) and angiogram.}

A-B: Note the typical bleeding pattern of a posterior circulation hemorrhage on CT demonstrating blood in the 4th ventricle (arrow) and cerebellar hematoma (arrowhead). C-E: Selective vertebral artery (VA) angiographic imaging and 3D-rotational angiography showing irregularity and the formation of 2 saccular aneurysms (arrows) along adjacent inter-PICA communicating arteries with an occluded L PICA (double arrow).

A brainstem arteriovenous malformation (AVM) with associated aneurysms was initially suspected. On exam, the patient was stuporous. She withdrew her limbs to pain, and cranial nerves were grossly intact. She was classified as Hunt and Hess Grade 4 and Fisher Grade IV. After the patient was stabilized in the neuro intensive care unit, cerebrospinal fluid (CSF) was diverted through ventriculostomy and proper work-up, including MRI brain, CT-angiogram, and catheter angiography, was performed. Catheter angiogram demonstrated that the left PICA was occluded at its origin. It was reconstituted by collateral supply from the right PICA through two communicating collateral arteries, each with one aneurysm, at the telovelomedullary segment 


\section{Cureus}

(Figures $1 C-1 E$ ). The aneurysm on the more proximal collateral was larger and assumed to have ruptured.

Operation and Postoperative Course

The patient was placed in prone position and underwent a midline suboccipital craniectomy and C1-laminectomy. A serpigineous right PICA, adjacent to a relatively straight left PICA beyond the communicating collateral arteries, was found. The left PICA was occluded at its origin. There was a $6.8 \mathrm{~mm}$ ruptured fusiform aneurysm on the more proximal collateral artery and a $5.2 \mathrm{~mm}$ unruptured aneurysm on the adjacent distal collateral artery. The larger fusiform aneurysm was resected. In order to maintain collateral flow to the left PICA, a side-to-side PICA-to-PICA anastomosis was performed. The smaller unruptured aneurysm was clipped, leaving a portion of its neck intact.

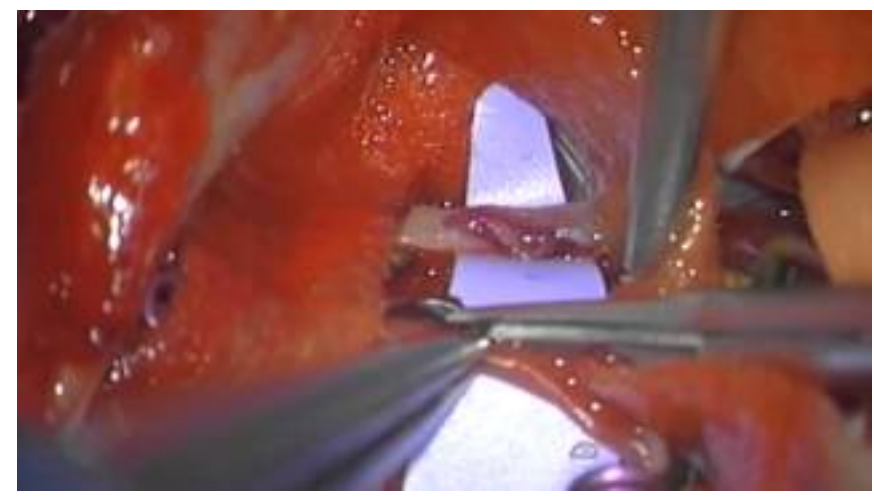

\section{VIDEO 1: Operative clip showing highlights of the operative technique for inter-PICA communicating collateral aneurysm clipping and side-to-side PICA-to-PICA bypass.}

View video here: https://www.youtube.com/watch?v=pA7Ms84GJX4

Intraoperative indocyanine green (ICG) video-angiography showed immediate patency of the bypass and postoperative 3D-rotational angiography confirmed sustained flow through the graft and no further filling of the remaining aneurysm neck (Figures $2 A, 2 B$ ). 


\section{Cureus}


\section{FIGURE 2: Postoperative 3D-rotational angiographic imaging and follow-up CT.}

A-B: Note side-to-side PICA-to-PICA bypass (double arrows) and occluded L PICA (arrows). CD: Three-month follow-up demonstrating shunt failure and subsequent shunt-revision.

The patient ultimately required permanent CSF diversion and therefore underwent ventriculoperitoneal shunting with a programmable strate-valve set at 0.5 . She also underwent tracheostomy. At one month follow-up, the patient was alert, oriented, with intact cranial nerve function, and following commands in all four extremities, though with slight weakness in both upper extremities. She was also without any sign of pseudomeningocele. She was transferred to a skilled nursing facility for further rehabilitation and eventually discharged. At three months, the patient returned with confusion and ventriculomegaly, and she underwent shunt-revision showing distal obstruction (Figures 2C, 2D). The valve was changed to a low-pressure valve. Postoperatively the patient did well. At discharge she was alert and oriented, could speak full sentences, and moved all four extremities on command, although she remained marginally weak in both upper extremities.

\section{Discussion}




\section{Cureus}

PICA-to-PICA communicating collateral artery aneurysms are extremely rare, with only five cases previously reported in the literature.

\begin{tabular}{|c|c|c|c|c|c|c|c|c|}
\hline Authors & Age & Sex & $\begin{array}{l}\text { Hunt } \\
\text { Hess } \\
\text { Grade }\end{array}$ & CT Findings & $\begin{array}{l}\text { Aneurysm(s) } \\
\text { Diameter } \\
(\mathrm{mm}) ; \text { Shape }\end{array}$ & Variation & Surgery & Outcome \\
\hline $\begin{array}{l}\text { Hlavin et } \\
\text { al. (1991) }\end{array}$ & 45 & $\mathrm{~F}$ & 3 & $\begin{array}{l}\text { Isolated blood in the } \\
\text { posterior horn of the left } \\
\text { lateral ventricle and mild } \\
\text { ventriculogmegaly }\end{array}$ & $<5$; saccular & $\begin{array}{l}\text { Absent right PICA and } \\
\text { AICA with the left PICA } \\
\text { supplying through an } \\
\text { inter-PICA collateral }\end{array}$ & Neck clipping & Excellent \\
\hline $\begin{array}{l}\text { Udono et } \\
\text { al. (1997) }\end{array}$ & 51 & $\mathrm{~F}$ & 3 & $\begin{array}{l}\text { Thick hematoma in the } \\
\text { cisterna magna, diffuse } \\
\text { SAH, and } \\
\text { intraventricular } \\
\text { hematoma }\end{array}$ & 2.5; saccular & None reported & Neck clipping & Excellent \\
\hline $\begin{array}{l}\text { Fujiwara } \\
\text { et al. } \\
\text { (1999) }\end{array}$ & 61 & $\mathrm{~F}$ & 3 & $\begin{array}{l}\text { Hematoma in the third, } \\
\text { fourth, and lateral } \\
\text { ventricles, and a mild } \\
\text { posterior fossa SAH }\end{array}$ & 3; saccular & $\begin{array}{l}\text { Absent left PICA with } \\
\text { the right PICA } \\
\text { supplying through an } \\
\text { inter-PICA collateral }\end{array}$ & Neck clipping & Excellent \\
\hline $\begin{array}{l}\text { Okuno } \\
\text { and } \\
\text { Onnishi } \\
(2000)\end{array}$ & 68 & M & 4 & $\begin{array}{l}\text { Thick SAH around the } \\
\text { medulla and massive } \\
\text { fourth-ventricular } \\
\text { bleeding }\end{array}$ & 3; fusiform & $\begin{array}{l}\text { Absent right PICA with } \\
\text { the left PICA supplying } \\
\text { through an inter-PICA } \\
\text { collateral }\end{array}$ & Trapping & Poor \\
\hline $\begin{array}{l}\text { Sugiyama } \\
\text { et al. } \\
(2012)\end{array}$ & 60 & M & 2 & $\begin{array}{l}\text { SAH with } \\
\text { intraventricular } \\
\text { hematoma in the third, } \\
\text { fourth, and bilateral } \\
\text { lateral ventricles }\end{array}$ & 2.5; fusiform & $\begin{array}{l}\text { Absent left VA, AICA, } \\
\text { and PICA with right } \\
\text { PICA supplying } \\
\text { through an right inter- } \\
\text { PICA collateral }\end{array}$ & Trapping & Excellent \\
\hline $\begin{array}{l}\text { Present } \\
\text { case }\end{array}$ & 76 & $\mathrm{~F}$ & 4 & $\begin{array}{l}\text { Significant SAH with a } \\
\text { bleeding pattern typical } \\
\text { of lower posterior } \\
\text { circulation hemorrhage }\end{array}$ & $\begin{array}{l}6.8 \text { and 5.2; } \\
\text { saccular }\end{array}$ & $\begin{array}{l}\text { Occluded left PICA } \\
\text { with communication to } \\
\text { the right PICA through } \\
\text { inter-PICA collaterals }\end{array}$ & $\begin{array}{l}\text { Resection, } \\
\text { neck } \\
\text { clipping, and } \\
\text { in situ } \\
\text { anastomosis }\end{array}$ & Excellent \\
\hline
\end{tabular}

\section{TABLE 1: Summary of 6 cases (including the present case) of posterior inferior cerebellar artery inter-communicating collateral artery aneurysms}

$\mathrm{SAH}=$ subarachnoid hemorrhage, $\mathrm{PICA}=$ posterior inferior cerebellar artery, VA = vertebral artery, AICA = anterior inferior cerebellar artery

Due to the radiologic appearance, the lesion was first suspected to be an AVM with two associated aneurysms. However, catheter angiogram confirmed the presence of two isolated saccular aneurysms on adjacent inter-PICA communicating collaterals originating between the 
right and left telovelomedullary segments.

PICA aneurysms distal to the anterior medullary segment are frequently associated with variants in circulation [3-4, 8]. All but one of the previously reported cases of inter-PICA collateral artery aneurysm involved congenital contralateral vascular hypoplasia that contributed to aneurysm development secondary to increased flow through the small collateral. A single absent PICA has so far been reported to be the most common vascular abnormality [4, 8-9]. One case described an absent left vertebral artery (VA), anterior inferior cerebellar artery (AICA), and PICA with contralateral supply through the inter-PICA communicating collateral; the right AICA was also connected to PICA and supplied its territory through this collateral artery [7]. Congenital variations like these are assumed to cause the development of collateral arteries enabling 'physiological' bypass of the abnormality and perfusion of the contralateral side. However, increased hemodynamic stress and turbulent flow through these small arteries is what presumably leads to aneurysm pathogenesis $[6,8]$.

All but two inter-PICA collateral aneurysms so far reported have been saccular. All but one developed on a straight portion of the collateral vessel as apposed to a branching point. It is unclear how branchless artery aneurysms develop along the straight portion of these arteries. In one series of multiple PICA aneurysms distal to the anterior medullary segment, 20 of 27 aneurysms arose at non-branching points [19]. On the basis of embryologic development, PICA develops through the axial and longitudinal anastomosis of plexiform vascular formations and remnants of the lateral channel to supply the inferior brainstem and cerebellum [20]. Sites of anastomosis have been suggested as susceptible areas for aneurysm development along the straight portions of PICA and its branches [19]. Interestingly, no reports of anterior inferior cerebellar artery (AICA)-to-AICA communicating artery aneurysms have been described, and just one case of a ruptured AICA-to-PICA communicating aneurysm was reported during postmortem analysis [21].

The present patient had a left PICA occluded at its origin, which reconstituted by a communication with the right PICA through two small collateral branching arteries at the telovelomedullary segment. Increased flow in the inter-PICA communicating collaterals presumably predisposed these vessels to the development of saccular aneurysms along the straight portion of these vessels at congenitally weak sites of vascular anastomosis. The intact aneurysm was clipped just above the neck to preserve flow through the inter-PICA collateral. However, due to the excellent bypass flow, the collateral vessel may be reluctant. As the telovelomedullary segment of PICA, proximal to the choroidal point, often possesses small perforating branches supplying the brainstem, revascularization was indicated; in situ side-toside PICA-to-PICA anastomosis was performed to maintain right-to-left perfusion of the PICAterritories. The proximity, parallel course, and similar size of the adjacent PICAs greatly facilitate their anastomosis with one another. Care should be taken, however, to avoid prolonged occlusion times during this anastomosis as small PICA perforating vessels $(<1 \mathrm{~mm})$ may be at risk. However, a longer clamping time has not been shown to have negative impact on clinical outcome in larger studies [22].

\section{Conclusions}

This unique case of inter-PICA communicating collateral aneurysm is, to our knowledge, the only reported case where multiple aneurysms are present on separate adjacent collateral arteries, with one PICA being occluded proximally and reconstituting secondary to the collateral arteries, and where, beyond aneurysm surgery, in situ bypass to restore adequate flow was performed. Clinicians should be aware of the possibility of this rare variant anatomy and corresponding pathology. In cases where hypoplasia of one side of the vertebral-basilar system is present, every effort should be made to maintain perfusion to the contralateral side. In situ bypass should be considered if the collateral must be sacrificed or if its integrity is in 
question, and especially if the pathology is proximal to the telovelotonsillary segment of PICA, in order to avoid serious risk of brainstem ischemia due to loss of flow through proximally arising PICA perforators.

\section{Additional Information \\ Disclosures}

Human subjects: All authors have confirmed that this study did not involve human participants or tissue. Conflicts of interest: In compliance with the ICMJE uniform disclosure form, all authors declare the following: Payment/services info: All authors have declared that no financial support was received from any organization for the submitted work. Financial relationships: All authors have declared that they have no financial relationships at present or within the previous three years with any organizations that might have an interest in the submitted work. Other relationships: All authors have declared that there are no other relationships or activities that could appear to have influenced the submitted work.

\section{Acknowledgements}

*M.M.M. and J.M.F. contributed equally to this work. Author contributions to the study and manuscript preparation include the following. Conception and design: Mortazavi, Sekhar. Acquisition of data: Frerich, Mortazavi. Analysis and interpretation of data: Frerich and Mortazavi. Drafting the article: Frerich, Mortazavi, and Sekhar.

\section{References}

1. Lister RJ, Rhoton AL Jr, Matsushima T, Peace DA: Microsurgical anatomy of the posterior inferior cerebellar artery. Neurosurgery. 1982, 10:170-199.

2. Salcman M, Rigamonti D, Numaguchi Y, Sadato N: Aneurysms of the posterior inferior cerebellar artery-vertebral artery complex: Variations on a theme. Neurosurgery. 1990, 27:1220.

3. Lewis SB, Chang DJ, Peace DA, Lafrentz PJ, Day AL: Distal posterior inferior cerebellar artery aneurysms: clinical features and management. J Neurosurg. 2002, 97:756-66.

4. Hlavin ML, Takaoka Y, Smith AS: A "PICA communicating artery" aneurysm: Case report . Neurosurgery. 1991, 29:926-9.

5. Nussbaum ES, Madison MT, Myers ME, Goddard J, Janjua T: Dissecting aneurysms of the posterior inferior cerebellar artery: retrospective evaluation of management and extended follow-up review in 6 patients. J Neurosurg. 2008, 109:23-7. 10.3171/JNS/2008/109/7/0023

6. Hudgins RJ, Day AL, Quisling RG, Rhoton AL Jr, Sypert GW, Garcia-Bengochea F: Aneurysms of the posterior inferior cerebellar artery. A clinical and anatomical analysis. J Neurosurg. 1983, 58:381-7.

7. Sugiyama S, Fujimura M, Inoue T, Shimizu H, Watanabe M, Tominaga T: Ruptured aneurysm of a posterior inferior cerebellar artery communicating artery. Case report and histological findings. Neurol Med Chir (Tokyo). 2012, 52:81-3.

8. Okuno S, Ohnishi H: Aneurysm of the posterior inferior cerebellar arteries/communicating artery. Cerebrovasc Dis. 2001, 12:276-9.

9. Fujiwara K, Ito J, Kanayama S: Multiple aneurysms of the PICA communicating artery: a case report (in Japanese). No Shinkei Geka. 1999, 27:177-82.

10. Udono H, Shiraishi T, Tsuji T, Abe M, Tabuchi K: True "PICA communicating artery" aneurysm: A case report (in Japanese). No Shinkei Geka. 1997, 25:763-6.

11. Phi JH, Lee SH, Son KR, Chung YS: Ruptured aneurysm originating from an aberrant medullary branch of the proximal posterior inferior cerebellar artery: Case report. Neurosurgery. 2010, 66:E221. 10.1227/01.NEU.0000360378.84853.A0

12. Anegawa S, Hayashi T, Torigoe R, Higashioka H, Tomokiyo M, Ogasawara T: Choroidal artery aneurysms of the posterior inferior cerebellar artery presented with fourth ventricular hemorrhage: Report of 2 cases (in Japanese). No Shinkei Geka. 1998, 26:729-735.

13. Horie N, Takahashi N, Furuichi S, et al.: Ruptured aneurysm at the choroidal branch of the 
posterior inferior cerebellar artery: a case report and review of the literature. Surg Neurol. 2003, 60:540-4.

14. Mclaughlin N, Bojanowski MW: Ruptured aneurysm at the choroidal branch of the posterior inferior cerebellar artery: a case report, review of the literature and proposed pathogenesis. $\mathrm{Br}$ J Neurosurg. 2005, 19:250-3.

15. Uranishi R, Ochiai C, Tejima T, Nagai M: A distal posterior inferior cerebellar artery aneurysm in the fourth ventricle: a case report (in Japanese). No Shinkei Geka. 1994, 22:1035-1038.

16. Schelhaas HJ, Brouwers PJ, van der Aa HE, Prevo RL: MRI locates a posterior fossa aneurysm in the fourth ventricle. Clin Neurol Neurosurg. 1998, 100:216-8.

17. Urbach H, Meyer B, Cedzich C, Solymosi L: Posterior inferior cerebellar artery aneurysm in the fourth ventricle. Neuroradiology. 1995, 37:267-9.

18. Wong GK, Zhu XL, Ng HK, Yu SC, Poon WS: Vermal hemorrhage with fourth ventricle extension due to ruptured posterior inferior cerebellar artery aneurysm. J Clin Neurosci. 2008, 15:203-5.

19. Horiuchi T, Tanaka Y, Hongo K, Nitta J, Kusano Y, Kobayashi S: Characteristics of distal posteroinferior cerebellar artery aneurysms. Neurosurgery. 2003, 53:589-95.

20. Padget DH: The development of the cranial arteries in the human embryo . Contrib Embryol. 1948, 32:205-262.

21. Jane JA: A large aneurysm of the posterior inferior cerebellar artery in a 1-year-old child . J Neurosurg. 1961, 18:245-7.

22. Griessenauer CJ, Poston TL, Shoja MM, Mortazavi MM, Falola M, Tubbs RS, Fisher WS: The impact of temporary artery occlusion during intracranial aneurysm surgery on long-term clinical outcome: Part I. Patients with subarachnoid hemorrhage. World Neurosurg. 2013, Mar 14: S1878-8750. 10.1016/j.wneu.2013.02.068 